\title{
Studi Intepretif Identifikasi dan Interaksi Intellectual Capital terhadap Kinerja Perusahaan
}

\author{
Sigit Hermawan \\ Fakultas Ekonomi Universitas Muhammadiyah Sidoarjo \\ Jln. Raya Gelam No. 250 Candi Sidoarjo \\ Email:tigis_her@yahoo.com \\ Silvia Herlina \\ Strategic Bussiness Unit Merpati Maintenance Facility Surabaya \\ Jl. Raya Juanda - Surabaya \\ Email: secil_lina@yahoo.com
}

\begin{abstract}
Abstrak
The objective of this research is to identify the key components of Human Capital (HC), Relational Capital (RC), and Structural Capital (SC), as well as to figure out each Components Interaction (CI) and how it relates with company's performance. This is qualitative research with interpretive approach. Data is validated by credibility and transferability test. The technique of analysis is Data Reduction. The research shows that the key components of HC, RC and SC in Business Strategic Unit of Merpati Maintenance Facility are model and framework, education, and vocational qualification for $\mathrm{HC}$ component; customer loyalty, favorable contracts, and licensing agreement for $R C$ component; patents, management process, expert network and teams for SC component. Interaction between IC's component occurs, influencing others and contributing to each component of IC or as whole. The key components of $\mathrm{HC}, \mathrm{RC}$, and SC should have interaction to give operational support in order to increase company's performance, both in its financial and non financial aspect.
\end{abstract}

Keywords: Intepretive Study, Intellectual Capital, Company's Performance

\section{PENDAHULUAN}

Intellectual Capital (IC) sebagai aset tersembunyi telah terbukti berperan dan penting bagi perusahaan di berbagai sektor industri dan jasa. Peran penting IC tersebut dibuktikan oleh berbagai penelitian, seperti penelitian Stewart (1997), IFAC (1998), Belkaoui (2003), Mageza (2004), Hsu (2006), Cabrita et al. (2007), Cohen and Kaimenakis (2007), Chen (2008), Sharabathi et al. (2010), Khalique et al. (2011), dan Hermawan (2011a dan 2011b), yang menyatakan bahwa IC sangat memengaruhi kinerja bisnis, meningkatkan nilai perusahaan, meningkatkan efektifitas organisasi, competitive advantage, dan juga menciptakan kesejahteraan. Berperannya $I C$ bagi perusahaan tidak terlepas dari peran setiap komponan $I C$ yang terdiri dari human capital $(H C)$, relational capital $(R C)$, dan structural capital (SC) ataupun juga interaksi antar komponen IC. Dengan melakukan interaksi antar komponen $I C$, setiap departemen atau devisi saling mendukung dalam aktivitas operasional ataupun strategis yang ada di perusahaan.

Interaksi yang intens dan berkelanjutan antar komponen IC inilah yang dirasakan masih sangat kurang oleh Strategic Business Unit Merpati Maintenance Facility (SBU MMF). Artinya daya dukung antar departemen atau devisi yang

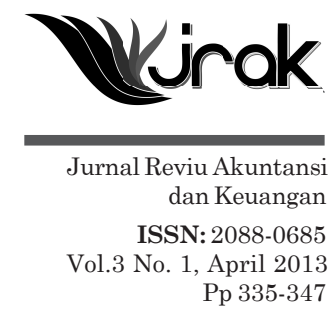


Studi

Intepretif

Identifikasi...

336 terkait dengan HC, RC, dan SC masih dirasa belum dilakukan dengan optimal. Akibatnya beberapa job order yang harusnya dapat dilakukan perusahaan tetapi lepas dan beralih ke perusahaan pesaing. Hal ini jelas merugikan perusahaan. Sementara itu, SBU MMF adalah perusahaan jasa perawatan pesawat milik Merpati Nusantara Airlines yang sarat dengan perubahan teknologi, sistem informasi dan komunikasi yang menuntut SBU MMF untuk melakukan up date cara dan kecepatan berbisnis serta harus selalu melakukan inovasi atas jasa layanan yang diberikan. $\mathrm{Hal}$ ini jel as membutuhkan IC dalam pengelolaannya. Pihak perusahaanpun juga belum mengetahui keberadaan IC yang dimilikinya walaupun secara tidak sadar sudah memilikinya. Oleh karenanya dibutuhkan identifikasi komponen kunci untuk HC, RC, dan SC. Dengan mengetahuinya, perusahaan akan lebih mudah untuk melakukan pengelolaan dalam bentuk interaksi antar komponen IC dalam bentuk support antar departemen atau devisi yang ada di SBU MMF yang akhirnya dapat meningkatkan kinerja perusahaan baik kinerja keuangan dan non keuangan.

Oleh karena itu, sangat penting untuk melakukan penelitian tentang identifikasi dan interaksi IC dikaitkan dengan kinerja perusahaan SBU M MF. Adapun tujuan penelitian ini adalah untuk mengidentifikasi komponen kunci HC, RC, dan SC, mengeksplorasi interaksi antar komponen IC, dan mengetahui keterkaitan antara IC dengan kinerja perusahaan.

\section{METODE}

\section{Jenis Penelitian}

J enis penelitian ini adalah kualitatif (Cresswell et al. 2007) dengan pendekatan intepretif (Smith and Osborn, 2007). J enis penelitian dan pendekatan ini sangat sesuai karena penelitian ini mengintepretasikan hasil in depth interview dengan informan kunci. Penelitian ini juga dimaksudkan untuk mendapatkan wawasan tentang sesuatu yang baru, sedikit diketahui, dan dapat memberikan rincian yang kompleks tentang fenomena yang sulit untuk diungkap ol eh metode kuantitatif (Strauss and Corbin, 2003). Penel itian ini banyak mengungkap tentang identifikasi dan interaksi komponen IC serta keterkaitannya dengan kinerja perusahaan.

\section{Lokasi Penelitian}

Lokasi penelitian ini adalah Strategic Bussiness Unit Merpati Maintenance Facility atau SBU MMF yang beralamat di J I. Raya J uanda - Surabaya. Alasan penel itian ini dilakukan di SBU M MF karena core business perusahaan ini sangat berkaitan erat dengan teknologi dan semakin ketatnya bisnis di bidang layanan jasa maintenance penerbangan. Dengan mengidentifikasi komponen kunci dan melakukan interaksi IC yang optimal di semua departemen atau devisi, diharapkan akan dapat meningkatkan kinerja perusahaan secara keseluruhan.

\section{Fokus Penelitian}

Fokus penelitian ini adalah untuk mengidentifikasi komponen kunci HC,SC dan RC, serta untuk mengetahui interaksi antara komponen IC dan mengaitkannya dengan kinerja perusahaan. I dentifikasi komponen kunci HC, SC, dan RC yang dimaksud adalah komponen kunci paling penting dan berperan untuk aktivitas utama di komponen HC, SC, dan RC. Interaksi antar komponen IC dan kinerja perusahaan yang dimaksud adalah keterkaitan atau daya dukung antar komponen IC yang bermanfaat untuk aktivitas operasional antar departemen atau divisi sehingga dapat meningkatkan kinerja perusahaan secara keseluruhan. 
Informan kunci dalam penelitian ini ditentukan dengan cara judgment

(Marshall, 1996) karena kekhususan data terkait dengan aktivitas HC, SC, dan

RC du SBU MMF. Adapun informan kunci dari penelitian ini adalah sebagai berikut:

1. General Manager Marketing \& Sales (Bapak GO); untuk mendapatkan data pendukung sekaligus mengkaji interaksi Relational (Customer) Capital terhadapa kinerja M MF.

2. General Manager Finance \& Administration (BapakAS); untuk mendapatkan data pendukung sekaligus mengkaji interaksi Human Capital terhadap kinerja MMF.

3. General Manager Quality Assurance (Bapak DP); untuk mendapatkan data pendukung sekaligus mengkaji interaksi Structural Capital terhadap kinerja MMF.

4. Sales \& Customer Service Officer (Bapak MS); untuk mengkaji komponen kunci Intellectual Capital Asset pada Relational Capital di SBU MMF.

\section{Teknik Pengumpulan Data}

Teknik pengumpulan data dilakukan dengan in depth interview, observasi, dan dokumentasi (Marshall, 2006). Proses pengumpulan data dilakukan mulai bulan A pril - J uli 2012. In depth interview dilakukan dengan menggunakan wawancara semi terstruktur yang berpedoman pada panduan wawancara. Panduan wawancara disusun berdasarkan tujuan penelitian yang telah ditetapkan dengan ditunjang ol eh teori dan konsep yang relevan. Peneliti menggunakan voice notes recorder Blackberry dan form wawancara untuk merekam data hasil wawancara. Observasi dilakukan dengan cara menjadi bagian sebagai seorang pengamat pada obyek penelitian. Dokumentasi dilakukan dengan menggali data di internal perusahaan ataupun artikel dan dokumen lain yang relevan dengan penelitian ini.

\section{Keabsahan Data}

Keabsahan data penelitian ini dilakukan dengan credibility dan transferability (Senton, 2004). Credibility dilakukan dengan cara triangulasi sumber dan triangulasi metode (Hussien, 2009). Transferability dilakukan dengan cara membuat laporan hasil penelitian secara parsimoni, terinci, sistematis, dan dapat dipercaya.

\section{Teknik Analisis Data}

Teknik analisis data dalam penel itian ini dilakukan dengan analisis reduksi data (Miles and Huberman, 1984). Proses analisis reduksi data dalam penelitian ini dimulai dengan menelaah seluruh data yang tersedia dari berbagai sumber di SBU MMF. Setelah dikaji, langkah berikutnya adalah membuat rangkuman untuk setiap kontak atau pertemuan dengan informan. Dalam merangkum data biasanya ada satu unsur yang tidak dapat dipisahkan dengan kegiatan tersebut. Kegiatan yang tidak dapat di pisahkan ini disebut membuat abstraksi, yaitu membuat ringkasan yang inti, proses, dan persyaratan yang berasal dari informan tetap dijaga. Berdasarkan rangkuman yang dibuat ini kemudian peneliti melakukan reduksi data yang kegiatannya mencakup unsur-unsur spesifik termasuk (1) proses pemilihan data atas dasar tingkat relevansi dan kaitannya dengan setiap kelompok data, (2) menyusun data dalam satuan-satuan sejenis. Pengelompokkan data dalam satuan yang sejenis ini juga dapat di ekuivalenkan sebagai kegiatan kategorisasi/ variable, (3) membuat koding data sesuai dengan kisi-kisi kerja penelitian. Kegiatan lain yang masih termasuk dalam mereduksi data yaitu kegiatan memfokuskan, menyederhanakan dan mentransfer dari data kasar ke catatan lapangan. Dalam penelitian kualitatif-naturalistik, ini merupakan kegiatan kontinyu dan oleh karena 
itu peneliti perlu sering memeriksa dengan cermat hasil catatan yang diperoleh Identifikasi... dari setiap terjadi kontak antara peneliti dengan responden informan kunci.

\section{HASIL DAN PEMBAHASAN}

\section{Identifikasi Komponen Kunci Human Capital, Relational Capital dan Structural Capital di SBU MMF}

Penelitian ini dilakukan dengan cara membuat daftar pertanyaan untuk wawancara yang akan diajukan pada informan kunci, yaitu GM Marketing \& Sales, GM Finance \& Administrati on dan GM Quality Assurance. Pada saat penelitian, proses recording dilakukan untuk mempermudah proses analisis data termasuk melakukan observasi sebagai bagian dari proses triangulasi metode. Berikut hasil penelitiannya.

a. Human Capital

Penelitian dilakukan dengan mengadakan melakukan in depth interview dengan informan kunci yakni GM Finance \& Administration dan mengadakan observasi langsung pada kegiatan training, serta upaya peningkatan pengetahuan dan kemampuan para pegawai yang ada di SBU MMF. Selanjutnya mengkaji hasil wawancara tersebut dan melakukan cross check dengan hasil dokumentasi training yang ada di SBU MMF. Hasilnya elemen intellectual capital asset untuk human capital yang dimiliki oleh SBU MMF ialah

1. Model and Frame work (Model dan kerangka kerja)

Berupa tata kelola dalam proses bisnis di SBU MMF yang mendasari seorang individual dalam menjalankan pekerjaannya. Seperti skema flow chart yang dibuat oleh pegawai di SBU MMF.

2. Education (Pendidikan)

Standar pendidikan minimum yang harus ditempuh pegawainya. Seperti pendidikan minimum untuk bagian administrasi adalah D3 dan untuk engineer harus lulusan dari sekolah penerbangan minimal S1 dan memiliki basic license aircraft.

3. Vocational Qualification (Kualifikasi Kejuruan)

Kualifikasi kejuruan untuk engineer ialah berdasarkan general license yang dimi liki, meliputi A1, A2, A3, A4, C1, C2, C4.

4. Know how (Tahu bagaimana)

Pegawai bekerja berdasarkan kemampuan yang dia miliki, dalam hal ini meliputi bagaimana peran pegawai dalam menyelesaikan pekerjaannya dan strategi apa yang dia lakukan untuk mengatasi masalah pekerjaan yang dia hadapi.

5. Work related knowledge (Bekerja pengetahuan terkait)

Pegawai bekerja berdasarkan pengetahuan yang dia miliki misal nya menyelesaikan pekerjaannya berdasarkan pengetahuan yang sebel umnya dia dapatkan.

6. Occupation assessment (Penilaian pekerjaan)

Penilaian pekerjaan berdasarkan hasil kerja atau prestasi kerja yang dia berikan kepada perusahaan. Termasuk kontribusinya terhadap perusahaan dan bagaimana dia menyelesaikan pekerjaannya dengan baik, benar dan tepat waktu.

7. Psychometric assessment (Penilaian psycometri)

Perusahaan mengadakan physical test untuk mengadakan recruitment pegawai sekaligus untuk mengadakan regenerasi pada structural di SBU MMF. 
8. Work-related competences (Bekerja kompetensi terkait)

Pegawai bekerja berdasarkan kompetensi yang dia miliki. Yaitu mel iputi kemampuan dia dalam mengolah data dan untuk engineer berdasarkan pengalaman dia dalam bekerja di pesawat.

9. Cultural Diversity (Keragaman budaya)

Terdapat keragaman budaya di SBU MMF dan karyawan dipilih dari kalangan dan suku yang berbeda-beda.

Berdasarkan semua el emen tersebut yang saat ini di butuhkan oleh SBU MMF ialah model, frameworks, dan psychometric assessment karena pada saat ini SBU MMF sedang merancang bisnis proses perusahaan guna mengurangi kegiatan-kegiatan yang kurang efisien. GM Finance $\&$ Administration menyatakan hal tersebut:

“Elemen intellectual capital asset untuk human capital yang sangat penting dan dominan pada saat ini ialah frameworks dan psychometric assessment. Bisnis proses di SBU MMF masih dibenahi karena dikhawatirkan masih banyak kegiatan yang tidak efisien. Untuk pendidikan pada saat ini masih belum di SBU MMF. Karena pada dasarnya pendidikan itu penting tapi sementara masalah faktornya kita masih butuh hidup dulu selanjutnya pengembangannya seperti apa. Dan setelah framework sudah jelas, efisien dan efektif juga lainnya mengikuti." (Petikan wawancara dengan Bapak AS, GM Finance $\&$ Administration tanggal 6J uli 2012).

\section{b. Relational Capital (Customer Capital)}

Penelitian dilakukan dengan in depth interview bersama GM Marketing \& Sales dan mengadakan observasi langsung pada proses pelayanan pelanggan yang ada di SBU MMF. Selanjutnya dilakukan kajian hasil wawancara tersebut dan melakukan cross check dengan hasil dokumentasi perjanjian kontrak sekaligus proses bisnis atau kegiatan di divisi Marketing \& Sales SBU MMF. $\mathrm{Hal}$ ini dilakukan sebagai bagian dari triangulasi metode untuk credibility data. Peneliti juga melakukan penelitian tambahan berupa wawancara dengan salah satu Marketing Officer di SBU MMF. Hal ini dilakukan sebagai bagian dari triangulasi sumber untuk credibility data.

Berdasarkan hasil penelitian diketahui bahwa el emen intellectual capital asset untuk relational capital yang dimiliki ol eh SBU MMF ialah

1. Customer loyalty (Kesetiaan pelanggan)

Keinginan dan minat pelanggan untuk selalu mendaftarkan pesawatnya untuk melakukan inspeksi perawatan pesawat di SBU M MF. Hal ini berdasarkan hubungan relationship di waktu lampau sehingga menarik minat pelanggan untuk mendaftarkan pesawatnya di SBU MMF.

2. Favorable contracts (Kontrak yang menguntungkan)

Perjanjian kerjasama antara kedua belah pihak yaitu antara pelanggan dengan pihak SBU MMF. Yaitu berupa surat kontrak kerjasama antara pelanggan dengan SBU MMF.

3. Licensing agreements (Perjanjian lisensi)

Perjanjian berlisensi yang dikeluarkan ol eh sejuml ah lembaga perwakilan otorisasi kelaikan udara. Seperti contoh sertifikat otorisasi dari: Directorate General of Civil Aviation, Department of Civil Aviation of LAO PDR, Civil Aviation Authority of the Philippines, European Aviation Safety Agency.

4. Brands (Merek)

Berupa sertifikat yang dikeluarkan oleh SBU MMF setelah melaksanakan inspeksi perawatan pesawat berupa: Certificate Release to Service dan 
Studi

Intepretif

Identifikasi...

340 sertifikat untuk inspeksi pada component pesawat yaitu berupa: Authorized Release Sertificate. Sertifikat tersebut beregistrasi resmi SBU MMF dan tidak bisa disalah gunakan oleh pihak lain.

5. Customer names, purchasehistory (Nama pelanggan, sejarah pembelian) Berupa daftar nama pelanggan dan sejarah pembeliannya yang di-entry dalam computer dan tersusun rapi dalam file divisi Marketing \& Sales.

6. Backlog orders (Backlog pesanan)

Yaitu merupakan akumulasi dari pekerjaan yang belum terlaksana terutama pesanan pelanggan yang telah terisi untuk jasa perawatan pesawat.

7. Distribution channel (Saluran distribusi)

Berupa broker yang dimiliki oleh perusahaan, relasi perusahaan yang membantu mempromosi kan SBU M MF dan juga pelanggan yang memilik sejarah hubungan kerja sama di SBU M MF yang membantu mempromosikan SBU MMF di penerbangan lain.

8. Business collaboration (J oint Ventures) (Kolaborasi bisnis)

Hubungan kerjasama dengan pihak lain yang saling menguntungkan. Seperti contoh: SBU M MF melakukan inspeksi perawatan pesawat dan ketika ada salah satu item pekerjaan yang SBU MMF belum capable (mampu) maka SBU M MF akan melemparnya ke pihak lain namun masih dalam under cover SBU MMF.

Semua elemen-elemen tersebut penting dan mutlak di perlukan sebagai sarana pembangun relational capital yang baik dan efisien dalam SBU MMF. Hal ini juga dibenarkan juga dengan pernyataan dari GM Marketing \& Sales yaitu:

"Menurut saya tidak bisa untuk difavoritkan kategori untuk elemen intellectual capital mana yang lebih dominan karena kita adalah bisnisjasa jadi hampir semua elemen intellectual capital diperlukan di SBU MMF." (Petikan wawancara dengan Bapak GO, GM Marketing \& Sales tanggal 10J uli 2012).

Berdasarkan identifikasi elemen-el emen intellectual capital asset untuk relational capital yang sangat penting di SBU MMF ialah customer loyalty, dan selanjutnya ialah favourable contract. Hal ini juga dibenarkan dengan pernyataan dari salah satu Sales \& Cust. Service Officer di SBU M M F yaitu:

"Dalam SBU M MF untuk relational capital lebih kepada customer loyalty, dan selanjutnya lebih kepada favourable contract. Karena favourable contract itu menyangkut value contact, komitmen yang lebih dikedepankan. Hal ini karena market kita kan sudah banyak jaringan. Supaya kita dapat menciptakan customer yang loyal harus ada favourable contract." (Petikan wawancara dengan Bapak MS, Sales \& Cust. Service Officer pada tanggal 6 Agustus 2012)

\section{c. Structural/Organizational Capital}

Penelitian dilakukan dengan in depth interview bersama GM Quality Assurance dan mengadakan observasi langsung pada proses bisnis yang ada di SBU M MF. Selanjutnya dilakukan kajian hasil wawancara tersebut dan melakukan cross check dengan hasil dokumentasi flow chart pekerjaan sekaligus regulasi yang diterapkan di SBU MMF. Hal ini sebagai bagian dari triangulasi metode. Penelitian ini membagi structural / organizational capital menjadi dua, yakni intellectual property dan infrastructure capital. Berdasarkan hasil penelitian, el emen intel lectual capital asset untuk structural / organizati onal capital yang dimiliki ol eh SBU M M F dalam intellectual property ialah:

1. Patents (Paten)

Hak paten yang dimiliki SBU MMF yaitu berupa sertifikat otorisasi untuk mendesain dan memodifikasi component / instrument pesawat. Sertifikat ini yaitu Design Organization Approval (DOA). 
2. Copyright (Hak Cipta)

Berupa hak cipta untuk check list pekerjaan yang dibuat ol eh engineering untuk digunakan sebagai pedoman pelaksanaan pekerjaan engineer di SBU MMF.

3. Design right (Hak desain)

Berupa hak desain untuk check list pekerjaan yang di buat oleh engineering untuk digunakan sebagai pedoman pelaksanaan pekerjaan engineer di SBU MMF.

4. Trade secrets (Rahasia dagang)

Informasi yang tidak diketahui oleh umum di bidang teknologi dan/atau bisnis, mempunyai nilai ekonomi karena berguna dalam kegiatan usaha dan dijaga kerahasiaannya oleh SBU MMF.

5. Service marks (Merek layanan)

Suatu logo, moto, symbol serta ungkapan yang dimiliki ol eh SBU MMF dalam melakukan kompetensi bisnis dengan para kompetitornya untuk mengi dentifikasikan suatu produknya. Adapun moto dari SBU MMF ialah "Cost Effective Solution to Keep Flying".

6. Trade dress (Visualisasi perdagangan)

Bentuk kekayaan intelektual yang berorientasi pada tampilan visual suatu produk atau kemasannya (atau bahkan desain bangunan) yang menunjukkan sumber produk kepada konsumen. Dalam hal ini produk di SBU MMF ialah jasa perawatan pesawat, dimana SBU MMF meningkatkan kinerja hasil mutu pekerjaan, kerapian dan keindahan dalam penyusunan final report yaitu tampilan cover final report yang menarik serta lay out hangar perawatan pesawat.

Sementara itu, elemen intellectual capital asset untuk structural / organizational capital yang dimiliki oleh SBU MMF dalam infrastructure capital ialah:

1. Management process (Proses manajemen)

Berupa flow chart pekerjaan dan work instruction atau intruksi pekerjaan yang telah dilegalisasi dan tertuang dalam buku AMO QC Manual di SBU MMF

2. Expert network $\&$ teams ( aringan ahli dan tim)

Dalam SBU MMF jaringan ahli dan team ini yaitu: Information Technoloqy Team, Planner for I nspection dan Engineering.

3. Management philosophy (Filosofi manajemen)

Yaitu ide-ide tentang praktik pengelolaan terbaik. Ada sudut pandang berbeda mengenai cara terbaik untuk mengelola sebuah organisasi. Sudut pandang ini tel ah digunakan ol eh para manager sukses sebel umnya di SBU MMF dan diteruskan kepada manager yang baru. Berupa praktik mengedepankan customer satisfaction dan pengaturan jadwal inspeksi perawatan pesawat.

4. Corporate culture (Budaya perusahaan)

Budaya organisasi di SBU MMF ialah mengutamakan on time performance dan kedisi plinan. Dimana setiap pegawai dituntut untuk disiplin dan menyelesaikan pekerjaannya dengan tepat waktu.

5. Information systems (Sistem informasi)

SBU MMF mengelola sistem informasi sendiri yang dinamakan dengan MMF SIS yaitu kepanjang dari Merpati Maintenance Facility System Information Support.

6. Networking systems (Sistem jaringan)

Di SBU MMF menggunakan sistemjaringan Local Area Network (LAN). 
Studi

Intepretif

Identifikasi...
7. Financial relations (Hubungan keuangan)

SBU MMF mempunyai hubungan keuangan dengan Bank Mandiri.

8. Sales tools (Alat-al at penjualan)

Berupa email dan surat penawaran langsung. Selain daripada itu SBU MMF juga mengadakan Launching dan Family Gathering yang dihadiri oleh beberapa perusahaan airlines.

9. Knowledge bases (Basis pengetahuan)

Basis pengetahuan di SBU M MF yaitu berdasarkan Civil Aviation Safety Regulation 145 (CASR 145), Maintenance Manual Books, Service Bulletin dan juga buku pengetahuan pemeliharaan pesawat lainnya.

10. Corporate value (Nilai perusahaan)

Para operasi filosofi atau prinsip-prinsip yang menuntun perilaku internal organisasi serta hubungan dengan pelanggan, mitra, dan pemegang saham. Nilai-nilai inti biasanya dirangkum dalam pernyataan misi dari SBU MMF yaitu "Give to costumer as our best service to Customer Satisfaction with solution of expense effectiveness and time minimum". J adi dalam perusahaan mengedepankan pelayanan yang terbaik untuk kepuasan pelanggan dengan biaya yang efektif dan waktu yang minimum.

Berdasarkan semua elemen tersebut, komponen penting intel lectual property ialah patents sedangkan untuk infrastructure capital ialah management process Dengan adanya management process dapat membantu mengurangi kegiatan-kegiatan yang kurang efisien dan memperlanjar proses produksi jasa perawatan di SBU MMF. Hal ini juga dibenarkan oleh pernyataan dari GM Quality Assurance yaitu:

“Dalamintellectual capital asset untuk Intellectual property yang paling penting ialah patent dan untuk infrastructure capital yaitu management proses karena itu kan harus ada prosedurnya." (Petikan wawancara dengan Bapak DP, GM Quality Assurancetanggal 6J uli 2012).

Berdasarkan hasil penelitian dapat disimpulkan bahwa komponen penting untuk HC, SC, dan RC di SBU MMF ialah:

a. Human Capital:

1. Model and Frame work (Model dan kerangka kerja)

2. Education (Pendidikan)

3. Vocational Qualification (Kualifikasi Kejuruan)

b. Relational Capital

1. Customer loyalty (Kesetiaan pelanggan)

2. Favorable contracts (Kontrak yang menguntungkan)

3. Licensing agreements (Perjanjian lisensi)

c. Organizational Capital

1. Patents (Paten)

2. Management process (Proses manajemen)

3. Expert network \& teams ( aringan ahli dan tim)

\section{Interaksi Antar Komponen Intellectual Capital}

a. Interaksi antara Human Capital dengan Structural Capital

Human capital memiliki peranan yang erat dengan structural capital . Karena setiap orang mempunyai kontribusi yang berbeda-beda untuk perusahaan. J ika kontribusinya baik maka akan memacu terciptanya structural capital yang baik pula. Dengan adanya personil atau pegawai yang mempunyai kemampuan tinggi 
dan berwawasan luas maka menciptakan sumber daya manusia yang baik yang menunjang terbentuknya sistem operasional perusahaan dan budaya perusahaan yang baik pula. Sehingga potensi kemampuan dari pegawai tersebut dapat dimanfaatkan secara maksimal demi tercapainya structural capital yang tinggi di SBU MMF. GM Finance \& Administration menyatakan bahwa:

"Iya ada kontribusi Human Capital dengan structural capital. Human capital memiliki kapasitas yang berbeda-beda dan kontribusi yang berbeda-beda pula. Sehinggajika dipilih orang-orang yang baik dengan menempatkan pada posisi yang baik pula maka akan ada added value untuk perusahaan." (Petikan wawancara dengan Bapak AS, GM Finance \& Administration tanggal 6J uli 2012).

Hal ini juga dibenarkan dengan pernyataan dari GM Quality Assurance yaitu:

"Hubungan antara structural capital dengan human capital seperti dengan put the right man to the right place jadi jika human capitalnya bagus tetapi tidak sesuai penempatannya, saya rasa itu adalah suatu hambatan bagi perusahaan. Artinya orang tersebut tidak tereksplore dengan maksimal, karena sebetulnya dia mampu lebih untuk bisa mendukung tujuan dari perusahaan tetapi karena tempatnya tidak tepat yang tentunya sangat berpengaruh terhadap produk." (Petikan wawancara dengan Bapak DP, GM Quality Assurancetanggal 6J uli 2012).

Salah satu contoh bahwa human capital berperan pada structural capital ialah bahwa di SBU MMF menempatkan pegawai yang berkualitas tinggi, berlisensi dan mempunyai pengalaman lebih banyak di divisi Quality Assurance. $\mathrm{Hal}$ ini ditujukan agar pegawai tersebut mampu menciptakan work instruction yang bertujuan untuk memberi instuksi pekerjaan kepada para pegawai demi memperlancar proses bisnis yang ada di SBU MMF. Berdasarkan data dokumentasi bahwa SBU MMF telah mentraining pegawainya untuk meningkatkan human capital. Hal ini juga terlihat dengan adanya observasi langsung dari penel iti bahwa telah diadakan training untuk para pegawai di SBU MMF. Training tersebut diadakan untuk meningkatkan kualitas pegawai di SBU MMF.

\section{b. Interaksi antara Human Capital dengan Relational Capital}

Human capital memiliki kontribusi yang sangat besar terhadap Relational capital. Karena setiap orang memiliki kemampuan yang berbeda-beda sehingga kemampuan mereka untuk menarik customer yang masuk juga berbeda-beda pula. Beberapa customer cenderung memilih untuk mendaftarkan pesawatnya untuk melakukan inspeksi di perusahaan pada marketing officer yang tel ah di percayainya. Hal juga dibenarkan dengan pernyataan dari GM Finance \& Administration yaitu:

"Begitu pula dengan custumer capital juga berperan terhadap human capital. Seperti contoh customer A ingin berhubungan dengan orang A, nah ini kapasitasnya berbedabeda. J ika orang lain pasti butuh waktu untuk mendapatkan kepercayaan dari customer. (Petikan wawancara dengan Bapak AS, GM Finance \& Administration tanggal 6J uli 2012).

Pernyataan tersebut dibenarkan juga oleh GM Marketing \& Sales, seperti komentar berikut ini:

"Relational capital itu memiliki peranan yang sangat penting dengan human capital. Karena saling mengisi, hal ini tidak bisa dilepas karena hubungan antara customer itu adal ah hubungan antara human yang menjadi modal utama." (Petikan wawancara dengan Bapak GO, GM Marketing \& Sales tanggal 6J uli 2012).

Dengan demikian pemanfaatan sumber daya manusia yang ada di perusahaan secara maksimal dan pengembangan potensi diri para pegawai akan memacu tercapainya kemampuan yang tinggi sehingga menarik minat relasi dan customer 
Studi

Intepretif

Identifikasi...

344 untuk melakukan kerja sama khususnya dalam inspeksi perawatan pesawat. Dengan demikian hal ini akan meningkatkan relational capital yang dimiliki SBU MMF. Salah satu contoh human capital berperan pada relational capital dapat terlihat dari frekuensi customer yang selalu mendaftarkan pesawatnya pada marketing officer yang sama. Contoh: Asialink Cargo selalu mendaftarkan pesawatnya untuk melakukan perawatan pesawat melalui Bapak MS selaku marketing officer di SBU MMF. Hal ini karena Bapak MS telah mendapatkan kepercayaan dari Asialink Cargo.

\section{c. Interaksi antar Structural Capital Terhadap Customer Capital}

Structural capital memiliki kontribusi yang besar pada relational capital. $\mathrm{Hal}$ ini sesuai dengan motto dari SBU MMF yaitu customer satisfaction adalah kepuasan pelanggan. Untuk membangun kepuasan dan kepercayaan pelanggan tersebut SBU MMF harus memiliki tata kelola atau business proses yang baik. Selain daripada itu SBU MMF juga harus menciptakan sistem operasional perusahaan dan budaya perusahaan yang baik pula. Dengan demikian jika telah terbentuk structural capital yang baik di perusahaan maka akan menunjang timbulnya kepercayaan customer untuk bekerja sama atau melakukan inspeksi perawatan pesawat di SBU MMF. Hal ini dibenarkan ol eh pernyataan dari GM Marketing \& Sales yaitu:

"Perananannya antara relational capital dengan structural capital sangat erat. Semua company harus menerapkan hal ini. Ketiga hal tersebut sangat er at peranannya untuk menjalankan corporate culture yang baik. Gak ada hal ini perusahaan gak bisa maju yaitu human capital atau modal orang harus mengetahui konotasi , operational dan work related knowledge di perusahaan." (Petikan wawancara dengan Bapak GO, GM Marketing \& Sales tanggal 6J uli 2012).

\section{Selain itu GM Quality Assurance juga menyatakan bahwa:}

"Sebetulnya semua customer ingin di servis sedemikian rupa ol eh suatu organisasi seperti M MF ini nomer satu ialah customer satisfaction. Artinya human capital dan structural capital itu kita kelola dengan baik tentunya akan memenuhi apa yang diinginkan ol eh customer. Dengan proses bisnis yang kita ada juga ada konti busi sejarah relationship antara kita dengan customer." (Petikan wawancara dengan Bapak DP, GM Quality Assurancetanggal 6J uli 2012).

Salah satu contoh bahwa structural capital berperan pada customer capital dapat terlihat bahwa sebel um melakukan inspeksi perawatan pesawat perwakilan dari otorisasi pihak customer melakukan audit di SBU MMF. Hal ini bertujuan untuk mendapatkan keyakinan bahwa SBU MMF telah melaksanakan fungsi manajemen yang baik dan proses bisnis yang sesuai dengan peraturan yang berlaku. Selain daripada itu terdapat beberapa sertifikasi seperti: ISO, AMO 145 dari Dinas kelaikan udara, dari Civil Aviation Authority (CAA) Philippines dan Iain sebagainya yang telah diperoleh ol eh SBU M MF. Sertifikasi tersebut sebagai persyaratan yang harus dipenuhi untuk mendapakan kepercayaan atau otorisasi dari customer untuk melakukan inspeksi perawatan pesawat.

\section{Intellectual Capital Meningkatkan Kinerja SBU MMF}

Intellectual capital sangat berperan dan berkontribusi terhadap kinerja perusahaan. Dengan tercapainya intellectual capital yang baik maka akan membuat kinerja perusahaan semakin baik pula. Hal tersebut bisa dilihat dari produktifitas SBU M MF. Karena dalam hal ini ketiga elemen intellectual capital seperti human capital, relational capital dan structural capital ikut serta dalam terbentuknya managemen yang baik sehingga menunjang tercapainya kinerja SBU MMF yang baik pula. GM Finance $\&$ Administration menyatakan bahwa: 
“Peranan I ntellectual capital sangat menentukan kinerja perusahaan hal ini dapat dilihat dari sistem produktifitasnya. Misal nya dari SBU MMF jika ada capability (kemampuan) tetapi orangnya tidak improve (berkembang) maka akan membutuhkan waktu lama untuk memperbaiki sesuatu." (Petikan wawancara dengan Bapak AS, GM Finance \& Administration tanggal 6J uli 2012).

Pendapat Bapak AS tersebut di benarkan ol eh GM Marketing \& Sales, sebagai berikut yaitu:

"Peranan Intellectual capital sangat menentukan kinerja SBU MMF. J adi kalau orang tidak tahu education bagaimana dia bicara customer, bagaimana dia bicara hubungan pendistribusian, hubungan bisnis kolaborasi, kemudian fungsi manajemen." (Petikan wawancara dengan Bapak GO, GM Marketing \& Sales tanggal 6J uli 2012).

Sementara itu, GM Quality Assurance juga menyatakan hal yang sama, yakni:

"J ika semua elemen intellectual capital seperti human capital, structural capital dan customer capital berjalan dengan baik akan membawa profit bagi perusahaan." (Petikan wawancara dengan Bapak DP, GM Quality Assurancetanggal 6J uli 2012)

Dengan adanya personal skill yang tinggi yang dimiliki oleh perusahaan yang merupakan sumber dari inovasi, strategi, mimpi dari perusahaan dan proses reengineering, ditunjang dengan adanya kemampuan organisasi atau perusahaan dalam memenuhi proses rutinitas perusahaan dan strukturnya yang mendukung usaha karyawan untuk menghasilkan kinerja intel ektual yang optimal serta kinerja bi snis secara keseluruhan maka akan menciptakan suatu persepsi pasar yang positif bagi perusahaan di mata pasar. Dengan demikian akan meningkatkan modal pelanggan yang ada di SBU MMF. J ika ketiga elemen intellectual capital tersebut terpenuhi maka akan mendorong tercapainya kinerja SBU MMF yang baik dari sisi keuangan maupun non keuangan.

\section{SIMPULAN}

Berdasarkan hasil penelitian dapat diidentifikasi komponen kunci HC, RC, dan SC di SBU M MF, yakni model and framework, education, dan vocational qualification untuk komponen $\mathrm{HC}$; customer loyal ty, favorable contracts, dan licensing agreement untuk komponen RC; patents, management process, expert network and teams untuk komponen SC. Selanjutnya, bahwa interaksi antar komponen IC dapat terjadi, saling berperan, dan berkontribusi baik untuk setiap komponen IC ataupun juga I C secara keseluruhan. Akhirnya, dengan mengetahui komponen kunci $\mathrm{HC}, \mathrm{RC}$, dan SC yang pal ing berperan dan berkontribusi serta dapat saling berinteraksi dengan baik akan sangat membantu kelancaran operasional kegiatan SBU MMF sehingga dapat meningkatkan kinerja perusahaan baik untuk aspek kinerja keuangan maupun non keuangan.

\section{Saran}

Perusahaan tidak cukup hanya melakukan identifikasi dan interaksi antar komponen IC tetapi Iebih dari itu harus pula menentukan model pengelolaan IC yang efektif. Beberapa rekomendasi model pengelolaan IC yang dapat dilakukan, misal nya Comprehensive I ntellectual Capital Management (Al-Ali, 2003), Intellectual Capital Management (The MERITUM, 2001; 2002), dan Intellectual Capital Managing and Reporting (Nordika, 2001). 


\section{DAFTAR PUSTAKA}

Al-Ali, Nermien. Comprehensive I ntellectual Capital Management. J ohn Wiley \& Sons, Inc., Hoboken, N ew J ersey.

Belkaoui, Ahmed Riahi. 2003. Intellectual Capital and Firm PerformanceUS Firm. A Study of The Resource Based and Stakeholders View. J ournal of Intellectual Capital. Vol 4 No 2. pp 215-226

Cabrita, Maria do Rosario., J orge Landeiro de Vas., and Nick Bontis. 2007 Modelling The Creation of Value From Intellectual Capital: A Portuguese Banking Perspective, Int. J . Knowledge and Learning. Vol. 3, Nos. 2/3, pp. 266 - 280.

Chen, Yu-Shan. 2008. The Positif Effect of Green Intellectual Capital on Competitive Advantage of Firms. J ournal of Business Ethics. 77:271-286.

Cohen, Sandra, and Nikolaos Kaimenakis. 2007. Intellectual Capital and CorporatePerformance in Knowl edge-intensiveSMEs. The Learning Organizations. Vol 14 No 3, pp 241 - 262

Creswell, J ohn W., William E. Hanson., Vicki L Plano Clark., dan Alejandro Morales. 2007. Qualitative Research Designs: Selection and I mplementation. The Counseling Psychologist. Vol 35, No 2. March. Pp 236 -264.

Hermawan, Sigit. 2011a. The Integration of Intellectual Capital and Knowledge Management to I mprove theB usi ness Performance and Achieve the Competitive Advantage. Proceeding. International Seminar. 22 August. Faculty of E conomic and Business. Hasanuddin University. Makassar, Indonesia.

Hermawan, Sigit. 2011b. Optimalisasi Intellectual Capital Guna Meningkatkan Kinerja Bisnis I KM Batik dan Memenangkan Persaingan di CAFTA. Proceeding. Seminar Nasional. 1 Oktober. Fakultas Ekonomi dan Bisnis. Universitas Muhammadiyah Malang. Indonesia

Hsu, H siu-Yueh (Sonya). 2006. Knowledge Management and Intellectual Capital. Dissertation. Carbondale, USA: Southern IIlinois U niversity

Hussien, Ashatu. 2009. The Use of Triangulation in Social Science Research: Can Qualitative and Quantitative Methods be Combined ?. J ournal of Comparative Social Work.

International Federation of Accountants (IFAC). 1998. The Measurement And Management Of I ntellectual Capital: An Introduction. N ew York. USA.

J onathan A Smith and Mike Osborn. 2007. Interpretative Phenomenol ogical Analysis. Qualitative Psychology.

Khalique, Muhammad., J amal Abdul Nassir Shaari., Abu Hasan Md I sa., dan Adel Ageel. 2011. Role of Intellectual Capital on the Organizational Performance of Electrical SMEs in Pakistan. International J ournal of Business and Management. Vol 6, No 9. September.

Mageza, Petunia Zanele., 2004. Intel lectual Capital As A Creator of Wealth and Shareholder Value For An Organization. Short Dissertation. Rand Afrikaans University.

Marshall, Martin N. 1996. Sampling for Qualitative Research. Family Practice, An International J ournal. Vol 13, No 6. Oxford University Press.

Marshall. 2006. Data Collection Method. http://www.sagepub.com/upm-data/ 10985_Chapter_4.pdf. Diakses 20 Desember 2010, J am 19.45 WIB

Miles, Matthew B., and A Michael Huberman. 1984. Qualitative Data Analysis. Sage Publication, Inc.

Nordika, 2001. Intellectual Capital Managing and Reporting. A Report From The Nordika Project.

Senton, Andrew K. 2004. Strategies For Ensuring Trustworthiness in Qualitative Research Project. Education For Information. 22. 63 -75. 
Stewart, Thomas A. 1997. Intellectual Capital - The New Wealth of Organization. London: Nicholas Brealey.

Strauss, Anselm., dan J uliet Corbin. 2003. Dasar-Dasar Penelitian Kualitatif. Penerbit Pustaka Pelajar. Yogyakarta.

The Measuring Intangibles To Understanding and I mprove innovation Management (The MERITUM). 2001. Final Report. Project funded by the European Community under the Target Socio E conomic Research (TSER)

The Meritum Project. 2002. Guidelines for Managing and Reporting on Intangibles. http://www.pnbukh.com. Diakses 23 Maret 2010. J am 02.30 WIB 
